http://jmscr.igmpublication.org/home/ ISSN (e)-2347-176x ISSN (p) 2455-0450 crossref DOI: https://dx.doi.org/10.18535/jmscr/v9i2.09

\title{
Hypofraction... Revisited: The emerging role of shorter treatment schedules for locally advanced cancers during the COVID-19 pandemic
}

Authors

\author{
Dr Bindhu Joseph ${ }^{1}$, Dr Nithin Bhaskar $V^{2}$, Dr Nikhila $K \mathbf{R}^{3}$, \\ Dr Sanjay $\mathbf{R}^{4}$, Dr Lokesh $\mathbf{V}^{5}$
}

${ }^{1}$ Associate Professor, Department of Radiation Oncology, Kidwai Memorial Institute of Oncology

${ }^{2,3}$ Assistant Professor, Department of Radiation Oncology, Kidwai Memorial Institute of Oncology

${ }^{4}$ Senior Resident, Department of Radiation Oncology, Kidwai Memorial Institute of Oncology

${ }^{5}$ Head of the Department, Department of Radiation Oncology, Kidwai Memorial Institute of Oncology

\begin{abstract}
Introduction: The COVID-19 pandemic is now imposing an immense strain on the oncology health care system, both in terms of optimal cancer care and safe delivery and execution of treatment. The period of lockdown has also created additional concerns over completion of interrupted treatments, progression of disease, the delay and increasing waiting list in the backdrop of limited health care resources and personnel.

In Asian countries, a large bulk of patients present with locally advanced cancers of the head and neck, breast and cervix. However other cancers involving esophagus, lung and brain also impose a problem during the pandemic because of the morbidity and mortality associated with postponed treatment.

Purpose and Objectives: In the midst of the COVID-19 pandemic, priority to minimise the risk of exposure of infection to patients and health care personnel is critical in ensuring the sustenance and completeness of treatment. The authors would like to provide optional hypofractionated protocols supported by scientific data that may be used as an interval expedient during this crisis.

Materials and Methods: A systematic literature research was done using Pubmed and other search engines. The focus was on scientific rationale, clinical adaptability, manageable toxicity and with comparable treatment outcomes with the standards of care.

Conclusions: The authors propose shorter, hypofractionated protocols with the option of selective concurrent chemotherapy in the management of head and neck cancer as well as the potential of shorter treatment options for esophageal and lung cancers and high grade gliomas. A few alternatives for an integrated boost to counter the reduced availability of brachytherapy have also been elaborated on.

Keywords: COVID-19, locally advanced cancers, hypofractionation.
\end{abstract}

\section{Background}

The COVID-19 outbreak which started in Wuhan, China, in December 2019 and the subsequent global pandemic has resulted in several difficult challenges in the radiotherapeutic management of cancers. This is especially dramatic for Asian countries where the larger percentage of presentations are locally advanced and mandate early initiation of treatment. Majority of these cancers fall into the high risk group as per the 
conceptual frameworks charted out by ASTRO, ESTRO, ESMO, NHS, Cancer care Ontario and several regional boards. We also face a scenario more akin to the late pandemic stage because of the pending backlog of interrupted treatments as a result of stricter curfew restrictions.

In this setting, hypofractionation provides a very attractive and probably a crucial alternative for mitigating the damage done to existing cancer treatments as well as providing a safer alternative for future treatments. In the current article, the authors have attempted to provide evidence for protocols based on hypofractionated schemes that can be safely adopted to suit the COVID situation in a few key sites especially, locally advanced cancers of the head and neck, lung, esophagus and high grade gliomas especially glioblastoma.

\section{Methods}

The authors have conducted a detailed literature search covering articles from Pubmed and other search engines. Additional resources included updates from national and international webinars conducted recently addressing the issues faced by the radiation community in dealing with this crisis. The suggestions offered by the authors have been restricted to the management of locally advanced cancer, and the clinical scenario related to the same.

\section{Locally advanced Head and Neck Cancer (LAHNC)}

The standard of care for inoperable locally advanced cancers of the head and neck is concurrent chemo-radiation. The most commonly used schedule is $2 \mathrm{~Gy}$ per fraction to a total dose of 66-70Gy over a period of 7 weeks. For operable cancers a similar need for chemo irradiation is present when high risk factors exist.

The rationale for considering an alternative to the standard of care is the risk to benefit ratio in the pandemic scenario that would favour a shorter treatment duration, thus reducing the chance of exposure and death related to exposure. Even if not associated with serious infection, the positivity alone would result in interrupted treatment till the patient can be safely restarted. In addition to this, the staff who come in contact would need to be quarantined thereby, reducing the manpower. The impact of interruption of treatment and subsequent accelerated re-population will probably adversely impact the anticipated survival. In the past decade the wider availability of advanced technology has rekindled the interest in hypofractionation for countering accelerated repopulation. Younger patients with good general condition should still receive the standard of care when feasible.

Scenarios where hypofractionated scenarios can make an acceptable alternative may include:

- Limitation of machine access due to reduction in health care staff being affected/quarantined.

- Unacceptably long delay in initiating treatment because of prioritisation to clear backlog of interrupted treatments.

- Patients older than 65yrs with feeding procedure support and may not require inpatient care.

- As an alternative to boost the therapeutic potential when the facilities to provide concurrent chemotherapy are not available or not safe.

The possible hypofractionated schedules and trial based references are given in Table 1 . The authors have only considered schedules that reduce treatment time greater than a week.

Palliative regimens with short weekly regimen (Quad Shot and similar) can be considered for patients with an anticipated survival of $>4$ months. This gives an opportunity to consolidate with further cycles of radiotherapy if the patient responds.

Ngyun et $\mathrm{al}^{(1)}$ had reported 8 Gy fractionations repeated every week for 3 consecutive weeks to result in good palliation of symptoms. As a high dose per fraction was used, Intensity Modulated Radiation Therapy (IMRT) was required. A continuous regimen with five fractions of $4 \mathrm{~Gy}$ to a total dose of $20 \mathrm{~Gy}$ was tried by Paliwal et $\mathrm{al}^{(2)}$ with 2D technique. They reported good symptom palliation with acceptable toxicity $(<5 \%$ 
mucositis). As weekly fractionations may pose an increased risk for acquiring the infection from external contacts, the preferred palliative regimen for the COVID -19 situation would be 20-25 Gy completed over one week. It is advisable when using shorter high dose regimens to anticipate prolonged mucositis and ensure at home supportive care is communicated. Also, it would be wise to stress the importance of proper nutrition to the patients as this can potentially decrease unplanned admissions ${ }^{(3)}$

\begin{tabular}{|c|c|c|c|c|}
\hline \multicolumn{5}{|l|}{ Table 1} \\
\hline \multicolumn{5}{|c|}{ Radical regimens } \\
\hline Total dose & $\begin{array}{ll}\text { dose } & \text { per } \\
\text { fraction } & \end{array}$ & OTT & Background & Limitations \\
\hline 66Gy & $2.2 \mathrm{~Gy}$ & 6 weeks & $\begin{array}{l}\text { Franzees et al }{ }^{(4)} \text { in a randomised cohort } \\
\text { of } 145 \text { patients observed comparable } \\
\text { survival and toxicity }\end{array}$ & Requires IMRT facilities. \\
\hline 60Gy & $2.4 \mathrm{~Gy}$ & 5 Weeks & $\begin{array}{l}\text { Tandon et al }{ }^{(5)} \text { randomised cohort of } 60 \\
\text { patients showed comparable survival and } \\
\text { toxicity }\end{array}$ & $\begin{array}{l}\text { Patients in hypo fractionated arm } \\
\text { had significantly more fatigue }\end{array}$ \\
\hline \multicolumn{5}{|c|}{ Palliative Regimens } \\
\hline 24Gy & $8 \mathrm{~Gy}$ (weekly) & & $\begin{array}{l}\text { A critical review by Grewal et al } \\
\text { showed } 82 \% \text { symptom palliation with } \\
\text { three weekly fractions of } 8 \mathrm{~Gy}\end{array}$ & Requires IMRT facilities. \\
\hline $20 \mathrm{~Gy}$ & 4 Gy & 5 days & $\begin{array}{l}\text { Paliwal et al }{ }^{(2)} \text { have reported good } \\
\text { symptom palliation with acceptable side } \\
\text { effects (mucositis }<5 \% \text { ) }\end{array}$ & \\
\hline
\end{tabular}

\section{Non-Small cell Lung Cancer (NSCLC)}

In addition to the possibility of increasing susceptibility of lung cancer patients to COVID19, the chances of complications once a lung cancer patient gets infected is higher. Minimisation of travel and the risk of exposure would be desirable for safe uninterrupted treatment

The management of stage III and IV lung cancers is of particular concern as the risk benefit ratio is weighed upon by several factors. These include:

1. Possibility of increase susceptibility of the infection to patients during the long 5-6 week course

2. Increases chance of complications from COVID-19 ${ }^{(7)}$

3. The need for concurrent chemotherapy in advanced disease to allow for optimal survival benefit by standard of care.
These issues were evaluated in detail by the combined ESTRO-ASTRO $^{(8)}$ task group who have issued guidelines as practice recommendations. In the Asian set -up, these may have to be adapted slightly to accommodate the different form of presentation and limitation of advanced technology. As the majority of medical centers are facing a backlog of pending patient treatments, we would directly have to adopt guidelines for the late pandemic stage. There was strong consensus favouring hypofractionated radiotherapy as appropriate when radiotherapy was given alone or when chemotherapy was planned sequentially; and the majority agreed hypofractionation may not be advisable with concomitant radiochemotherapy.

This can be supported by emerging evidence favouring a four week treatment regimen for locally advanced NSCLC. Majority of the studies 
have employed modest hypofractionation of 2-3 Gy per fraction. In patients receiving radiation alone, three studies including those by Ngyun et al and Amini et $\mathrm{al}^{(9,10)}$, comparing standard fractionation to hypofractionation evidenced comparable toxicity and outcomes . A phase $\mathrm{II}^{(11)}$ by Maguire et al has shown that hypofractionated radiotherapy of 55 Gy in 20 fractions delivered over 4 weeks was both feasible and reasonably safe. The survival rates were also promising. The results using the same regimen from four UK centres, involving 609 patients were assessed ${ }^{(12)}$ and the data in terms of survival parameters was promising.

\begin{tabular}{|c|c|c|c|c|}
\hline \multicolumn{5}{|l|}{ Table 2} \\
\hline Evidence & Dose & Comparator & & \\
\hline Nguyen et al ${ }^{(9)}$ & 45 Gy/15\# & $60-66 \mathrm{~Gy} / 30-33 \#$ & $\begin{array}{l}\text { Response rates, LRC, and OS } \\
\text { comparable to those in the cohort } \\
\text { treated by a total dose of } 60-66 \mathrm{~Gy} \text { at } \\
2 \text { Gy per fraction over } 6 \text { to } 6.5 \text { weeks }\end{array}$ & $\begin{array}{l}\text { Retrospective } \\
\text { data. KPS 50- } \\
\text { 70. Only RT }\end{array}$ \\
\hline Amini et $\mathrm{al}^{(10)}$ & $45 \mathrm{~Gy} / 15 \#$ & $\begin{array}{l}\text { 60-63Gy over } 6 \\
\text { weeks }\end{array}$ & $\begin{array}{l}\text { no difference in cumulative incidence } \\
\text { of locoregional or distant failures } \\
\text { between the RT groups in the } \\
\text { presence of competing factors }\end{array}$ & $\begin{array}{l}\text { Retrospective } \\
\text { data. Only RT }\end{array}$ \\
\hline Din et al ${ }^{(12)}$ & $55 \mathrm{~Gy} / 20 \#$ & & $\begin{array}{l}\text { Large series of } 609 \text { patients. Showed } \\
\text { comparable results to those reported } \\
\text { for similar schedules }\end{array}$ & \\
\hline
\end{tabular}

\section{Locally Advanced Cervical Cancer}

Two thirds of all locally advanced cervical cancers present at Figo stage III/IV ${ }^{(13)}$ in India. Concurrent chemo-radiation (CCRT) followed by Brachytherapy (BT) is the established standard of care for locally advanced cancers of the cervix which may be paramount to improving survival and providing a better quality of life ${ }^{(13)}$. The effect of COVID-19 pandemic in the treatment of cervical cancer is two-fold. The extended concurrent external beam component of treatment requires 5-6 weeks to deliver 45-50 Gy with conventional fractionation. The second problem is the integration of brachytherapy boost to the high risk tumor volume without an unacceptable treatment gap. It is essential to note that locally advanced cervical cancers, with large volume residual disease post EBRT, would benefit only from advanced applications such as hybrid or interstitial brachytherapy, which may not be feasible in the current COVID -19 setting where resources are constrained.
To address the first issue, the authors have reviewed studies considering hypofractionation of the external beam component of treatment. The various schedules used have been listed in Table 3. All these employed 2-D conventional Radiotherapy. Although the local control reported were non inferior, acute grade 2 toxicity of $>20 \%$ as well as significantly higher rates of late proctitis and cystitis were observed. The chances of higher acute toxicity would result in treatment interruptions and defeat the purpose of planning a shorter treatment regimen. Radiobiological response pattern and sensitivity of the critical normal structures ie., rectum and bladder would preclude a safe response when larger volumes are treated to higher doses. The authors would recommend employing such regimens with extreme caution, using advanced technology and preferably limited to a severe shortage of resources. The use of concurrent platinum chemotherapy may accentuate the acute toxicity and may preferably be avoided in the current COVID - 19 scenario. 


\begin{tabular}{|c|c|c|c|c|}
\hline \multicolumn{5}{|l|}{ Table 3} \\
\hline \multicolumn{5}{|c|}{ Hypofractionated Regimen for Radical WPRT } \\
\hline Evidence & EBRT dose & $\begin{array}{l}\text { Dose per } \\
\text { fraction }\end{array}$ & Background & Limitations \\
\hline $\begin{array}{l}\text { Mishra et al } \\
(2017)\end{array}$ & $45 \mathrm{~Gy} / 18 \mathrm{Fr}$ & $2.5 \mathrm{~Gy}$ & $\begin{array}{l}\text { Local control rates } \\
\text { comparable to the } \\
\text { conventional fractionation, } \\
\text { Higher grade } 2 \text { toxicity but } \\
\text { not statistically significant }\end{array}$ & $\begin{array}{l}\text { Late toxicities not reported, } \\
\text { Concurrent cisplatin at similar } \\
\text { dose as with conventional } \\
\text { fractionation may be } \\
\text { responsible for numerically } \\
\text { higher grade2 toxicity }\end{array}$ \\
\hline $\begin{array}{l}\text { Mahobia et } \\
\mathrm{al}^{(15)} \\
(2015)\end{array}$ & $42 \mathrm{~Gy} / 15 \mathrm{Fr}$ & $2.8 \mathrm{~Gy}$ & $\begin{array}{l}\text { Local control and disease } \\
\text { free survival at one year } \\
\text { was comparable to } \\
\text { conventional fractionation, }\end{array}$ & $\begin{array}{l}\text { Statistically significant higher } \\
\text { incidence of acute toxicities - } \\
\text { vomiting, proctitis \& cystitis, } \\
\text { probably due to use of } \\
\text { concurrent Cisplatin with } \\
\text { hypofractionation }\end{array}$ \\
\hline $\begin{array}{l}\text { Komen A.A et } \\
\text { al (dissertation) } \\
(2014)\end{array}$ & $40 \mathrm{~Gy} / 16 \mathrm{Fr}$ & $2.5 \mathrm{~Gy}$ & $\begin{array}{l}\text { Local control comparable to } \\
\text { conventional fractionation } \\
\text { of other studies. Acute } \\
\text { Toxicities limited to grade } \\
2 . \quad \text { Concurrent } \\
\text { chemotherapy not used. }\end{array}$ & $\begin{array}{l}\text { No direct comparison with } \\
\text { conventional fractionation }\end{array}$ \\
\hline $\begin{array}{l}\text { Muckaden et al } \\
{ }^{(16)}(2002)\end{array}$ & 39 Gy/13 Fr & $3 \mathrm{~Gy}$ & $\begin{array}{l}\text { Local control and survival } \\
\text { at } 5 \text { years comparable to } \\
\text { conventional fractionation }\end{array}$ & $\begin{array}{l}\text { Higher grade } 2 \text { acute rectum \& } \\
\text { bladder toxicity }\end{array}$ \\
\hline
\end{tabular}

Patients with advanced disease presenting with severe vaginal bleeding/ bilateral hydroureteronephrosis with deranged renal parameters or severe pelvic pain may be beyond the possibility of cure. Such patients, who are expected to have a survival of less than a year may be considered for palliative radiotherapy.. The widely spaced palliative regimen of once a month dose of $10 \mathrm{~Gy} /$ Fraction suggested by several studies ${ }^{(17-20)(21)}$ may be revisited in the current covid scenario, to minimize the patient visits as well as achieve the intended palliation. The PMH 0-7-21 schedule of 7 Gy per fraction on day 0 , day 7 and day 21 is another useful option for palliation of symptoms ${ }^{(22)}$

The second issue of delivering the boost treatment, however, does have some promising alternatives that can be considered in the COVID19 situation with reduced access to brachytherapy facilities or timely treatment.

1. Simultaneous integrated boost (SIB):
Guerrero et $\mathrm{al}^{(23)}$ used SIB to simulate equivalent plans for patients with stage III cervical cancer to an total dose of $77.5 \mathrm{~Gy}$ with comparable toxicity parameters to the standard regimen .In this study the cervical boost volume received 3.1 Gy/Fraction. A few studies that have clinically employed SIB-IMRT are given in table 4.

Clinical advantages: This might be suitable for large volume primary disease as the dose can be adapted to the distorted anatomy. Incorporating adaptive replanning when available can allow for faster re-planning and positive nodes can be addressed simultaneously. The major limitation would be the availability of the higher technology required to deliver image guided treatment. 


\begin{tabular}{|c|c|c|c|c|}
\hline \multicolumn{5}{|l|}{\begin{tabular}{|l|} 
Table 4 \\
\end{tabular}} \\
\hline Evidence & $\begin{array}{l}\text { WPRT } \\
\text { Dose/Dose per } \\
\text { fraction }(\text { Gy) }\end{array}$ & $\begin{array}{l}\text { Boost Dose/ } \\
\text { Dose per } \\
\text { fraction }(G y)\end{array}$ & Background & Limitations \\
\hline \multicolumn{5}{|l|}{ Radical EBRT } \\
\hline $\mid \begin{array}{l}\text { Mazzola } \\
(24)(2017)\end{array}$ & $54 / 1.8$ & $66 / 2.2$ & $\mid \begin{array}{lr}\text { SIB in } 30 \text { patients }>70 \\
\text { years old, provided } \\
\text { comparable LC and } 3 \text { year } \\
\text { OS with conventional } \\
\text { fractionation, } r \text { Acute } \\
\text { toxicities limited to Grade2. }\end{array}$ & $\begin{array}{l}\text { PET-CT based target } \\
\text { delineation and VMAT } \\
\text { plans, which may not be } \\
\text { available in all centres }\end{array}$ \\
\hline $\begin{array}{l}\text { Vandecasteele } \\
\text { (25) et al (2013) }\end{array}$ & $45 / 1.8$ & $62 / 2.48$ & $\begin{array}{l}\text { SIB in } 30 \text { patients, No grade } \\
3 \text { and above acute toxicity } \\
\text { of bladder/recum. }\end{array}$ & $\begin{array}{l}\text { Used as neoadjuvant CT- } \\
\text { RT, pts underwent } \\
\text { surgery, so cannot } \\
\text { comment on local control }\end{array}$ \\
\hline
\end{tabular}

2. Hypofractionated boost SBRT/IMRT/3DCRT:

Hypofractionated image guided conformal radiotherapy would be the closest to mimicking HDR Brachytherapy. It maximizes the therapeutic ratio by allowing for a more circumscribed dose to be delivered. The advantage also applies to delivery, which may be more widely feasible. A hypofractionated boost can be delivered using 3 dimensional Conformal Radiotherapy (3 DCRT) or via IMRT/IGRT and also with 2D technique using bicentric arcs. Scheduling the delivery of hypofractionated EBRT boost on Saturdays may be done alike interdigitating Brachytherapy. Clinical examples of protocols that have employed the above are given in table 5

Even though the scientific data is not robust enough to suggest equivalence, the treatment can be delivered with manageable side effects and considerable efficacy in terms of safe completion of treatment within a favourable time frame.

\begin{tabular}{|c|c|c|c|c|}
\hline \multicolumn{5}{|l|}{ Table 5} \\
\hline \begin{tabular}{|l|} 
Evidence for \\
SBRT boost
\end{tabular} & $\begin{array}{l}\text { WPRT } \\
\text { Dose/ Dose per } \\
\text { fraction }(\mathbf{G y})\end{array}$ & \begin{tabular}{|lr} 
SBRT & Boost \\
$($ Dose/ & Dose \\
per & fraction $)$ \\
$(G y)$ & \\
\end{tabular} & Background & Limitations \\
\hline $\begin{array}{l}\text { Haas et } \\
(26)(2012)\end{array}$ & $50.4-61.2 / 1.8$ & $19.5 / 6.5-20 / 4$ & $\begin{array}{l}\text { CK boost used, Tumor BED = } \\
\text { 78-85 Gy achieved, } 100 \% \text { LC; no } \\
>\text { Grade } 2 \text { toxicity }\end{array}$ & $\begin{array}{l}\text { Limited no. of patients; } 6 \text { months } \\
\text { follow up }\end{array}$ \\
\hline $\begin{array}{l}\text { Marnitz et al } \\
(2013)\end{array}$ & $50.4 / 1.8$ & $30 / 6$ & $\begin{array}{l}\text { CK boost used, Tumor BED = } \\
108 \text { Gy achieved, } 100 \% \text { LC; no } \\
\text { > Grade } 2 \text { toxicity }\end{array}$ & $\begin{array}{l}\text { Limited no. of patients, } 14 \text { months } \\
\text { follow up }\end{array}$ \\
\hline $\begin{array}{l}\text { Kubicek et } \text { al }^{(28)} \\
(2013)\end{array}$ & $45 / 1.8$ & $25 / 5$ & Tumor BED=77Gy; 75\% LC & $\begin{array}{l}\text { MRI were used for target } \\
\text { delineation for boost phase, IGRT } \\
\text { with use of organ implanted radio- } \\
\text { opaque fiducial markers. } \\
1 / 11 \text { pts Grade } 3 \text { acute proctitis }\end{array}$ \\
\hline $\begin{array}{l}\text { Hsieh et al. } \\
(2013)\end{array}$ & $50.4 / 1.8$ & $16-27 / 3-4.5$ & $\begin{array}{l}\text { Tumor BED=91.2Gy; } 78 \% \text { LC at } \\
3 \text { years; }\end{array}$ & $\begin{array}{l}\text { Limited no. of patients } \\
1 / 9 \text { pts Grade } 3 \text { acute proctitis }\end{array}$ \\
\hline $\operatorname{Mantz}_{(2016)}^{\operatorname{Man}(2016)}$ & $45 / 1.8$ & $40 / 8$ & $\begin{array}{l}\text { Tumor BED of } 125 \text { Gy achieved, } \\
78.6 \% \text { LC at } 5 \text { years; no > Grade } \\
2 \text { toxicity }\end{array}$ & $\begin{array}{l}\text { PET/CT \& MRI were used for } \\
\text { target delineation for boost phase, } \\
\text { IGRT with use of organ implanted } \\
\text { radio-opaque fiducial markers. }\end{array}$ \\
\hline
\end{tabular}




\begin{tabular}{|l|l|l|l|l|}
\hline $\begin{array}{l}\text { Evidence for } \\
\text { 3DCRT boost }\end{array}$ & $\begin{array}{l}\text { WPRT Dose/ } \\
\text { Dose } \\
\text { per } \\
\text { fraction (Gy) }\end{array}$ & $\begin{array}{l}\text { 3DCRT Boost } \\
\text { Dose/ Dose per } \\
\text { fraction (Gy) }\end{array}$ & Background & Limitations \\
\hline Park et al ${ }^{(31)}$ & $50 / 2$ & $30 / 5$ & Total tumor BED of 105 Gy & $\begin{array}{l}\text { IGRT with use of organ implanted } \\
\text { radio-opaque fiducial markers. }\end{array}$ \\
\hline Chan et al ${ }^{(32)}$ & $45-50 / 1.8-2$ & $25.2 / 1.8-2$ & Total tumor BED of 85-90 Gy & \\
\hline $\begin{array}{l}\text { Barraclough et } \\
\text { al (33) }\end{array}$ & $40-45 / 2-2.5$ & $15-25 / 1.8-2.5$ & $\begin{array}{l}\text { Total tumor BED of 87 Gy, } \\
\text { comparable local control, 3 year } \\
\text { overall survival and toxicity } \\
\text { profile }\end{array}$ & \\
\hline BED = Biological effective dose; CK=CyberKnife; LC=local control \\
\hline
\end{tabular}

\section{High grade Glioma}

Even though high grade gliomas carry a poor prognosis, radiotherapy with concurrent chemotherapy has shown to improve survival ${ }^{(34)}$. Surgery followed by radiotherapy to a total dose of 60 Gy over a period of 6 weeks with concurrent chemotherapy remains the standard of care in good performance patients with Glioblastomas. ${ }^{(34)}$ In the pandemic scenario, these patients need some special mention.

- The neutropenia and lymphopenia as a result of concurrent temozolomide can be risky in patients with increased susceptibility to COVID 19 [age $>65$,KPS $<50$ and uncontrolled comorbidities.]
- The neurologic deficits that accompany the disease make them dependent on health care provider support and might pose a problem in terms of the need for prolonged in-patient admission.

- Benefits of hypofractionation have already been proven in low performance and eldery patients with glioblastoma ${ }^{(35-37)}$. However during the pandemic it may also be considered for providing a better risk benefit ratio to patients less than 65 years with significant comorbidities. MD Anderson has come out with practice guidelines to address this scenario.

\begin{tabular}{|c|c|c|c|}
\hline \multicolumn{4}{|l|}{ Table 6} \\
\hline Evidence & $\begin{array}{l}\text { Clinical } \\
\text { condition }\end{array}$ & Dose investigated & Background \\
\hline Roa et $\mathrm{al}^{(38)}$ & $>60 y r s$ & 40Gy/15fractions & $\begin{array}{l}\text { no survival difference when compared to } \\
60 \mathrm{~Gy} / 30 \#\end{array}$ \\
\hline J Perry et $\mathrm{l}^{(37)}$ & $\begin{array}{l}\text { Age }>\quad 65 y r s, \\
\text { good GC }\end{array}$ & $\begin{array}{l}40 \mathrm{~Gy} / 15 \text { fractions } \\
\text { with conc. TMZ }\end{array}$ & $\begin{array}{l}\text { Survival benefit with adding conc TMZ with } \\
40 \mathrm{~Gy} / 15 \#\end{array}$ \\
\hline Mallick et $\mathrm{al}^{(39)}$ & $\begin{array}{l}\text { Age }<65 \text { yrs. KPS } \\
>60\end{array}$ & $\begin{array}{l}\text { 60Gy/20fractons: } \\
\text { SIB with conc. TMZ }\end{array}$ & $\begin{array}{l}\text { Comparable survival outcomes with } 60 \mathrm{~Gy} / 30 \# \\
\text { with TMZ }\end{array}$ \\
\hline
\end{tabular}

\section{Esophageal cancer}

The commonest presentation of advanced esophageal cancer in Asian countries is potentially resectable and inoperable. Standard treatment for such scenarios consists of neoadjuvant chemoradiotherapy followed by surgery or definitive chemo irradiation. In addition to the long treatments, the associated dysphagia can lead to increased weight loss and associated need for inpatient care. It is preferred to consider a lower threshold for enteral nutrition to avoid acute admissions and rapid morbidity of early onset dysphagia $^{(3)}$.

Hypofractionation may be considered in the scenario of 1. Patients unfit for surgical management after neoadjuvant chemotherapy. 2 . 


\section{JMSCR Vol||09||Issue||02||Page 49-60||February}

Pre-operative set up where facilities for radical surgery are still functional.3.Radical definitive radiotherapy. Even though there are limited studies comparing neoadjuvant to radical chemoradiation in esophageal cancer, there is promising data to suggest they might have comparable outcomes ${ }^{(40)}$. The option of deferring 5Fu may be considered in the concurrent set up to avoid the need for inpatient care. Weekly platinum based chemotherapy with or without paclitaxel can be considered as an alternative.
If the risks of prolonged treatment are high and chemotherapy facilities are limited hypofractionated radiotherapy maybe a viable option. A recently published retrospective series by Jones et al ${ }^{(41)}$ has looked into $50 \mathrm{~Gy}$ in 16 fractions for tumors upto $5 \mathrm{~cm}$ and $50-52.5 \mathrm{~Gy}$ in 20 fractions for tumors upto $10 \mathrm{~cm}$ in length. They described the regimen to be safe and tolerable with promising survival outcomes. A few options of hypofractionated treatment regimens are given in table 7

\begin{tabular}{|c|c|c|c|}
\hline \multicolumn{4}{|l|}{ Table 7} \\
\hline Total Dose & \begin{tabular}{|l|} 
dose per \\
fraction
\end{tabular} & Background & Limitations \\
\hline \multicolumn{4}{|l|}{ Neo-adjuvant } \\
\hline $\begin{array}{l}30 \quad \mathrm{~Gy} / \quad 10 \\
\text { Fractions }\end{array}$ & 3 Gy & $\begin{array}{l}\text { Jiahua Luy et al }{ }^{(42)} \text { (2019) in a recent series of } 110 \text { patients } \\
\text { have found pathological downstaging similar to CRT with no } \\
\text { additional morbidity. }\end{array}$ & IMRT \\
\hline $\begin{array}{l}40 \mathrm{~Gy} / 15 \\
\text { fractions }\end{array}$ & $2.67 \mathrm{~Gy}$ & $\begin{array}{l}\text { Ning Li et al }{ }^{(43)} \text { (2018) established this schedule as optimal } \\
\text { MTD (maximal tolerated dose in Gastric cancer) }\end{array}$ & IMRT \\
\hline \multicolumn{4}{|l|}{ Radical } \\
\hline $54-60 G y$ & $3 \mathrm{~Gy}$ & $\begin{array}{l}\text { Maj B et al }{ }^{(44)}(2012) \text { in an RCT with } 110 \text { patients found } \\
\text { equivalent local control }\end{array}$ & \\
\hline $50 \mathrm{~Gy}$ & $3.12 \mathrm{~Gy}$ & Christopher M Jones ${ }^{(41)}$ et al observed similar survival & \\
\hline
\end{tabular}

\section{Summary}

The COVID-19 Pandemic has and will continue to have a significant impact on cancer treatment and care. The treatment recommendations suggested by the authors are only temporary alternatives that can be considered to mitigate the current burden on the radiotherapy community and are no way to be considered as substitutions for the standard of care.

\section{References}

1. Nguyen N-TA, Doerwald-Munoz L, Zhang H, Kim D-H, Sagar S, Wright JR, et al. 0-7-21 hypofractionated palliative radiotherapy: an effective treatment for advanced head and neck cancers. $\mathrm{Br} \mathrm{J}$ Radiol. 2015 May 19;88(1049):20140646.
2. Paliwal R, Kumar-Patidar A, Walke R, Hirapara P, Jain S, Raj-Bardia M. Palliative Hypo-fractionated Radiotherapy in Locally Advanced Head and Neck Cancer with Fixed Neck Nodes. Vol. 5, Iranian journal of cancer prevention. Cancer Research Center, Shahid Beheshti University of Medical Sciences; 2012. p. 178-82.

3. Howard A, Banks S, Owens R, Ward L, Warner N, Mukherjee S. The role of active nutritional intervention in patients receiving chemoradiation (CRT) for oesophageal cancer. Vol. 30, Annals of Oncology. Elsevier; 2019. p. iv78.

4. Franzese C, Fogliata A, Franceschini D, Navarria P, Cozzi L, Tomatis S, et al. Impact of hypofractionated schemes in 
radiotherapy for locally advanced head and neck cancer patients. Laryngoscope. 2020;130(4):E163-70.

5. Tandon S, Gairola M, Ahlawat P, Rawat S, Aggarwal A, Sharma K, et al. Randomized controlled study comparing simultaneous modulated accelerated radiotherapy versus simultaneous integrated boost intensity modulated radiotherapy in the treatment of locally advanced head and neck cancer. Vol. 30, Journal of the Egyptian National Cancer Institute. 2018. p. 107-15.

6. Grewal AS, Jones J, Lin A. Palliative Radiation Therapy for Head and Neck Cancers. Int J Radiat Oncol Biol Phys. 2019 May 22;

7. Zhang L, Zhu F, Xie L, Wang C, Wang J, Chen $\mathrm{R}$, et al. Clinical characteristics of COVID-19-infected cancer patients: a retrospective case study in three hospitals within Wuhan, China. Annals of Oncology. Elsevier;

8. Guckenberger $\mathrm{M}$, Belka $\mathrm{C}$, Bezjak A, Bradley J, Daly ME, DeRuysscher D, et al. Practice recommendations for lung cancer radiotherapy during the COVID-19 pandemic: An ESTRO-ASTRO consensus statement. undefined(undefined).

9. Nguyen LN, Komaki R, Allen P, Schea RA, Milas L. Effectiveness of accelerated radiotherapy for patients with inoperable non-small cell lung cancer (NSCLC) and borderline prognostic factors without distant metastasis: a retrospective review. Vol. 44, International Journal of Radiation Oncology • Biology • Physics. Elsevier; 1999. p. 1053-6.

10. Amini A, Lin SH, Wei C, Allen P, Cox JD, Komaki R. Accelerated hypofractionated radiation therapy compared to conventionally fractionated radiation therapy for the treatment of inoperable non-small cell lung cancer. Vol. 7, Radiation oncology (London, England). BioMed Central; 2012. p. 33-33.
11. Maguire J, Khan I, McMenemin R, O'Rourke N, McNee S, Kelly V, et al. SOCCAR: A randomised phase II trial comparing sequential versus concurrent chemotherapy and radical hypofractionated radiotherapy in patients with inoperable stage III Non-Small Cell Lung Cancer and good performance status. Vol. 50, European Journal of Cancer. Elsevier; 2014. p. 2939-49.

12. Din OS, Harden SV, Hudson E, Mohammed N, Pemberton LS, Lester JF, et al. Accelerated hypo-fractionated radiotherapy for non small cell lung cancer: Results from 4 UK centres. Vol. 109, Radiotherapy and Oncology. Elsevier; 2013. p. 8-12.

13. Shrivastava S, Mahantshetty U, Engineer R, Chopra S, Hawaldar R, Hande V, et al. Cisplatin Chemoradiotherapy vs Radiotherapy in FIGO Stage IIIB Squamous Cell Carcinoma of the Uterine Cervix.

14. Mishra Subhasis, Niharika Panda. A Comparative Study to Evaluate the Role of Hypofractionated Radiotherapy With Concurrent Weekly Cisplatin Vs Conventional Radiotherapy with Concurrent Weekly Cisplatin in Advanced Carcinoma Cervix. Vol. 5, Sch. J. App. Med. Sci. 2017. p. 2809-16.

15. Mahobia Vijay Kumar, Rewadhkar Mahesh. Study of comparison of outcome between conventional versus hypofractionated radical radiotherapy alongwith Cisplatin as a Radiosensitizer in Stage IIIB cancer cervix. Vol. 5, indian journal of basic and applied medical research. p. 112-21.

16. Muckaden MA, Budrukkar AN, Tongaonkar HB, Dinshaw KA. Hypofractionated radiotherapy in carcinoma cervix IIIB: Tata Memorial Hospital experience. Indian J Cancer. 39(4):127-34. 
17. Boulware RJ, Caderao JB, Delclos L, Wharton JT, Peters LJ. Whole pelvis megavoltage irradiation with single doses of $1000 \mathrm{rad}$ to palliate advanced gynecologic cancers. Int $\mathbf{J}$ Radiat Oncol Biol Phys. 5(3):333-8.

18. Hodson DI, Krepart GV. Once-monthly radiotherapy for the palliation of pelvic gynecological malignancy. Gynecol Oncol. 16(1):112-6.

19. Halle JS, Rosenman JG, Varia MA, Fowler WC, Walton LA, Currie JL. 1000 cGy single dose palliation for advanced carcinoma of the cervix or endometrium. Int J Radiat Oncol Biol Phys. 12(11):1947-50.

20. Onsrud M, Hagen B, Strickert T. 10-Gy single-fraction pelvic irradiation for palliation and life prolongation in patients with cancer of the cervix and corpus uteri. Gynecol Oncol. 82(1):167-71.

21. Mishra SK, Laskar S, Muckaden MA, Mohindra P, Shrivastava SK, Dinshaw KA. Monthly palliative pelvic radiotherapy in advanced carcinoma of uterine cervix. J Cancer Res Ther. 1(4):208-12.

22. Yan J, Milosevic M, Fyles A, Manchul L, Kelly V, Levin W. A Hypofractionated Radiotherapy Regimen (0-7-21) for Advanced Gynaecological Cancer Patients. Clin Oncol. 2011 Sep 1;23(7):476-81.

23. Guerrero M, Li XA, Ma L, Linder J, Deyoung C, Erickson B. Simultaneous integrated intensity-modulated radiotherapy boost for locally advanced gynecological cancer: Radiobiological and dosimetric considerations. Vol. 62, International Journal of Radiation Oncology • Biology • Physics. Elsevier; 2005. p. 933-9.

24. Mazzola R, Ricchetti F, Fiorentino A, Levra NG, Fersino S, Di Paola G, et al. Weekly Cisplatin and Volumetric-
Modulated

Arc

Therapy

With

Simultaneous Integrated Boost for Radical Treatment of Advanced Cervical Cancer in Elderly Patients: Feasibility and Clinical Preliminary Results. 2016/07/08. Vol. 16, Technology in cancer research \& treatment. SAGE Publications; 2017. p. $310-5$

25. Vandecasteele K, Makar A, Van den Broecke R, Delrue L, Denys H, Lambein $\mathrm{K}$, et al. Intensity-modulated arc therapy with cisplatin as neo-adjuvant treatment for primary irresectable cervical cancer. Vol. 188, Strahlentherapie und Onkologie. 2012. p. 576-81.

26. Haas JA, Witten MR, Clancey O, Episcopia K, Accordino D, Chalas E. CyberKnife Boost for Patients with Cervical Cancer Unable to Undergo Brachytherapy. Vol. 2, Frontiers in oncology. Frontiers Research Foundation; 2012. p. 25-25.

27. Marnitz S, Köhler C, Budach V, Neumann O, Kluge A, Wlodarczyk $\mathrm{W}$, et al. Brachytherapy-emulating robotic radiosurgery in patients with cervical carcinoma. Vol. 8, Radiation Oncology. 2013. p. 109.

28. Kubicek GJ, Xue J, Xu Q, Asbell SO, Hughes L, Kramer N, et al. Stereotactic Body Radiotherapy as an Alternative to Brachytherapy in Gynecologic Cancer. Vol. 2013, BioMed Research International. Hindawi Publishing Corporation; 2013. p. 898953.

29. Hsieh C-H, Tien H-J, Hsiao S-M, Wei MC, Wu W-Y, Sun H-D, et al. Stereotactic body radiation therapy via helical tomotherapy to replace brachytherapy for brachytherapy-unsuitable cervical cancer patients - a preliminary result. 2013/02/04. Vol. 6, OncoTargets and therapy. Dove Medical Press; 2013. p. 59-66.

30. Mantz CA. Stereotactic Body Radiation Therapy as a Boost Alternative for 
Nonmetastatic Cancer of the Cervix and Endometrium: Disease Control and Quality of Life Outcomes From a Phase 2 Trial at 3 Years' Minimum Follow-up. Vol. 96, International Journal of Radiation Oncology • Biology • Physics. Elsevier; 2016. p. E286.

31. Park HC, Shimizu S, Yonesaka A, Tsuchiya K, Ebina $\mathrm{Y}$, Taguchi $\mathrm{H}$, et al. High dose three-dimensional conformal boost using the real-time tumor tracking radiotherapy system in cervical cancer patients unable to receive intracavitary brachytherapy. 2009/12/29. Vol. 51, Yonsei medical journal. Yonsei University College of Medicine; 2010. p. 93-9.

32. Chan P, Yeo I, Perkins G, Fyles A, Milosevic M. Dosimetric comparison of intensity-modulated, conformal, and fourfield pelvic radiotherapy boost plans for gynecologic cancer: a retrospective planning study. Vol. 1, Radiation oncology (London, England). BioMed Central; 2006. p. 13-13.

33. Barraclough LH, Swindell R, Livsey JE, Hunter RD, Davidson SE. External Beam Boost for Cancer of the Cervix Uteri When Intracavitary Therapy Cannot Be Performed. Vol. 71, International Journal of Radiation Oncology - Biology • Physics. Elsevier; 2008. p. 772-8.

34. Stupp R, Mason WP, van den Bent MJ, Weller M, Fisher B, Taphoorn MJB, et al. Radiotherapy plus Concomitant and Adjuvant Temozolomide for Glioblastoma. New Engl J Med. 2005 Mar 10;352(10):987-96.

35. Malmström A, Grønberg BH, Marosi C, Stupp R, Frappaz D, Schultz H, et al. Temozolomide versus standard 6-week radiotherapy versus hypofractionated radiotherapy in patients older than 60 years with glioblastoma: the Nordic randomised, phase 3 trial. Lancet Oncol. 2012 Sep 8;13(9):916-26.
36. Bauman GS, Gaspar LE, Fisher BJ, Halperin EC, Macdonald DR, GRegory Cairncross J. A prospective study of shortcourse radiotherapy in poor prognosis glioblastoma multiforme. Vol. 29, International Journal of Radiation Oncology • Biology • Physics. Elsevier; 1994. p. 835-9.

37. Perry JR, Laperriere N, O'Callaghan CJ, Brandes AA, Menten J, Phillips C, et al. Short-Course Radiation plus Temozolomide in Elderly Patients with Glioblastoma. Vol. 376, New England Journal of Medicine. Massachusetts Medical Society; 2017. p. 1027-37.

38. Roa W, Brasher PMA, Bauman G, Anthes M, Bruera E, Chan A, et al. Abbreviated Course of Radiation Therapy in Older Patients With Glioblastoma Multiforme: A Prospective Randomized Clinical Trial. Vol. 22, Journal of Clinical Oncology. American Society of Clinical Oncology; 2004. p. 1583-8.

39. Mallick S, Kunhiparambath H, Gupta S, Benson R, Sharma S, Laviraj MA, et al. Hypofractionated accelerated radiotherapy (HART) with concurrent and adjuvant temozolomide in newly diagnosed glioblastoma: a phase II randomized trial (HART-GBM trial). Vol. 140, Journal of Neuro-Oncology. 2018. p. 75-82.

40. Rackley T, Leong T, Foo M, Crosby T. Definitive chemoradiotherapy for oesophageal cancer -- a promising start on an exciting journey. Vol. 26, Clinical Oncology (Royal College of Radiologists (Great Britain). 2014. p. 533-40.

41. Jones CM, Spencer K, Hitchen C, Pelly T, Wood B, Hatfield $P$, et al. Hypofractionated Radiotherapy in Oesophageal Cancer for Patients Unfit for Systemic Therapy: A Retrospective Single-Centre Analysis. Vol. 31, Clinical Oncology. Elsevier; 2019. p. 356-64.

42. Lyu J, Liu T, Li T, Li F, Wang Q, Wang J, 
et al. Comparison of efficacy, safety, and costs between neoadjuvant hypofractionated radiotherapy and conventionally fractionated radiotherapy for esophageal carcinoma. 2019/05/22. Vol. 8, Cancer medicine. John Wiley and Sons Inc.; 2019. p. 3710-8.

43. Li N, Wang X, Tang Y, Zhao D, Chi Y, Yang L, et al. A prospective phase I study of hypo-fractionated neoadjuvant radiotherapy for locally advanced gastric cancer. Vol. 18, BMC cancer. BioMed Central; 2018. p. 803-803.

44. Ma J-B, Wei L, Chen E-C, Qin G, Song Y$\mathrm{P}$, Chen X-M, et al. Moderately hypofractionated conformal radiation treatment of thoracic esophageal carcinoma. Asian Pac J Cancer Prev APJCP. 2012;13(8):4163-7. 